\title{
Medical Electronic Prescription for Home Respiratory Care Services (PEM-CRD) at a Portuguese University Tertiary Care Centre (2014-2018): A Case Study
}

\author{
Ricardo Alves $\left.{ }^{1,+} \mathbb{(}\right)$, Cátia Caneiras ${ }^{2,3,+} \mathbb{C}$, Ana Isabel Santos ${ }^{1,4}$, Patricia Barbosa ${ }^{1}$, \\ João Cardoso ${ }^{5,6}$, Paulo Caseiro ${ }^{2}$, Maria João Vitorino ${ }^{2}$, João Pereira ${ }^{1}$ and Ana Escoval ${ }^{1, *}$ \\ 1 National School of Public Health, Nova University Lisbon, 1600-560 Lisbon, Portugal; \\ r.alves@ensp.unl.pt (R.A.); ai.santos@ensp.unl.pt (A.I.S.); patbarbosa@ensp.unl.pt (P.B.); \\ jpereira@ensp.unl.pt (J.P.) \\ 2 Associação Portuguesa de Cuidados de Saúde ao Domicílio (APCSD), 1250-068 Lisbon, Portugal; \\ ccaneiras@medicina.ulisboa.pt (C.C.); secretariado@apcsd.pt (P.C.); direcao@apcsd.pt (M.J.V.) \\ 3 Laboratório de Microbiologia na Saúde Ambiental (EnviHealthMicro Lab), Instituto de Saúde \\ Ambiental (ISAMB), Faculty of Medicine, Lisbon University, 1649-026 Lisbon, Portugal \\ 4 Hospital Administration, Centro Hospitalar Universitário de Lisboa Central (CHULC), 1169-050 Lisbon, Portugal \\ 5 Pulmonology Department, Centro Hospitalar Universitário de Lisbon Central (CHULC), \\ 1169-050 Lisbon, Portugal; joaocardoso@meo.pt \\ 6 Nova Medical School, Nova University Lisbon, 1169-056 Lisbon, Portugal \\ * Correspondence: anaescoval@ensp.unl.pt; Tel.: +351-21-751-2100 \\ + These authors contributed equally to this manuscript.
}

Received: 15 October 2020; Accepted: 21 November 2020; Published: 25 November 2020

check for updates

\begin{abstract}
Home respiratory care (HRC) is the provision of healthcare services at the place of residence of patients or their families, with the aim of meeting needs mainly resulting from chronic respiratory conditions, permanent disability, or terminal illness. In 2016, an innovative electronic prescription system, PEM-CRD, was fully implemented for HRC services in Portugal. To date, no study has addressed the impact of the execution of this digital innovation. For this purpose, we carried out an analysis of the prevalence and number of prescriptions for people with chronic respiratory diseases receiving HRC in the Lisbon metropolitan area, during 2014-2018, using the information obtained from the PEM-CRD database. The data analysis shows that while the number of patients receiving HRC treatment with a prescription has remained stable over the last four years, the number of prescriptions has significantly dropped since 2016 (2016-2018), with consequent paper and processes efficiency. The implementation of the digital Medical Electronic Prescription for Home Respiratory Care tool (PEM-CRD) and consequent dematerialization of these processes has increased the efficiency of prescribing in HRC. Additionally, the possibility of obtaining data through the PEM-CRD allows the monitoring of the evolving prevalence of therapies, improving the health services optimization and allowing reporting on data other than medicines.
\end{abstract}

Keywords: home respiratory care; long-term oxygen therapy; home mechanical ventilation (HMV); electronic prescription; digital transformation; sustainability reporting; sustainable digitalization; e-health; Portugal

\section{Introduction}

Home respiratory care (HRC) is the provision of services (including adaptation to therapy by health professionals, 24/7 specialized phone services, patient training, and availability of equipment and consumables) at the place of residence of patients or their families, with the aim of meeting 
needs mainly resulting from chronic respiratory conditions, permanent disability, or terminal illness [1]. HRC includes critical services to the population such as oxygen, aerosol, and ventilation therapies, namely, continuous positive airway pressure (CPAP) for moderate to severe obstructive sleep apnea syndrome (OSAS) or bilevel home-mechanical ventilation (HMV) for chronic obstructive pulmonary disease (COPD), neuromuscular diseases, and other respiratory disorders [2].

Chronic obstructive pulmonary disease, chronic bronchitis, and emphysema represented the group of chronic diseases with the fifth highest self-reported prevalence worldwide [3,4]. The prevalence of this group of respiratory diseases increased from 4\% to 5.8\% between 2005 and 2014, reaching an additional 500,000 people in Portugal-almost half of whom were over 65 years old. According to estimates by the General Directorate of Health (DGS) [5,6], chronic respiratory diseases affect more than $40 \%$ of the total population, with the COPD estimate being $14.2 \%$ for people older than 40 years old. There are few epidemiological studies carried out on OSAS worldwide, but in those, the prevalence was between 3\% and 7\%, and was significantly higher in men and in older or obese populations [7]. Despite these estimates, the underdiagnosis of people with chronic respiratory failure and OSAS is very significant (around 86.8\% for COPD), and represents an important challenge in the treatment of these chronic respiratory diseases [8-11].

This increasing evolution of the prevalence of chronic respiratory diseases has been accompanied by critical organizational changes, especially concerning the model of HRC [12]. In 2011, DGS defined the clinical guidance rules for home respiratory care (HRC) in Portugal, and these were subject to updates in 2015 [13-15]. Moreover, the improvement of the accessibility and quality of these services to the user must be associated with a sustainable use of the multiple resources necessary for the provision of health care, implying the provision of a set of appropriate mechanisms for this purpose [2,16,17]. Additionally, we should remark the contribution of the homecare association APCSD (Associação Portuguesa de Cuidados de Saúde ao Domicílio), which represents more than 95\% of existing patients, and the extensive upgrade performed by homecare providers on their organizations by upskilling their staff and recruiting additional clinical professionals as well as by accomplishing a significant technical upgrade of the level of medical devices following the specifications of the national public contract "CP 2013/100". Thus, it was necessary to add information systems aligned with the public procurement instruments and clinical guidance, in order to ensure effective and high-quality access to health care as required by citizens' clinical states.

Following the recommendations presented in 2010 by the National Commission for Home Respiratory Care [18], the prescription of HRC became electronic at the end of 2013 through a computer application provided by the Shared Services of the Ministry of Health (SPMS) [19]. However, only in 2016 was this fully implemented to include the HRC medical prescription. This application is integrated in the Medical Electronic Prescription tool despite being a specific development for Home Respiratory Care (PEM-CRD) [6].

The PEM-CRD was made available by the SPMS to all institutions and services integrated in the Portuguese National Health Service (SNS). It incorporates the updated clinical guidelines of the General Health Directorate (DGS) [6] and the contractual and administrative rules which resulted from the national public tender that resulted from a related national framework agreement renewal in 2017 [20]. However, to date, no study has addressed the impact of the execution of this digital innovation. Thus, this study aims to analyse the impact of the implementation of the electronic prescription system (PEM-CRD) issued between 2014 and 2018 at a tertiary care centre in Lisbon. For this purpose, we carried out an analysis of the prevalence and number of prescriptions for people with chronic respiratory diseases receiving home respiratory care in the Lisbon metropolitan area. 


\section{Materials and Methods}

\subsection{Study Design and Population}

We conducted a cross-sectional study in which a secondary retrospective analysis of the database was carried out between 2014 and 2018, relating to the prescriptions of HRC users residing in the geographic area of influence surrounding the Centro Hospitalar Universitário de Lisboa Central (CHULC).

After a formal request and authorization by the SPMS, data relating to treatment prescriptions for oxygen, aerosol, and ventilation therapy were provided in 2019 . The study population consisted of patients with a prescription for home respiratory care between 2014 and 2018, who belonged to the geographic area surrounding the CHULC (a tertiary hospital centre) and the Agrupamento de Centros de Saúde (ACES) Lisbon Central (a grouping of health centres providing primary care). The following data were collected from the database: sociodemographic data (gender, age); date of prescription; type and subtype of treatment (aerosol therapy, ventilation therapy, adjunct to ventilation therapy, oxygen therapy, ambulation oxygen, short- and long-term oxygen therapy (LTOT), and palliative oxygen therapy and equipment); type of prescription (renewal, initial, or modification); and clinical context (hospital care and primary health care). Individuals with voided prescriptions were excluded from the analysis.

\subsection{Statistical Analysis}

Statistical analysis was performed using the Statistical Package for Social Sciences ${ }^{\circledR}$ (IBM ${ }^{\circledR}$ SPSS $^{\circledR}$ Statistics) version 23, for Windows. The calculation of frequency distribution was performed for the analysis of categorical variables, while for continuous variables, the mean (and standard deviation) and median (and interquartile ranges) were calculated. Differences between groups were compared using the chi-square test, with a $p<0.01$ considered significant.

\subsection{Ethical Approval}

The project has been approved by the Health Ethics Committee of Centro Hospitalar Universitário de Lisboa Central (CHULC), under the ethical approval code 462/2017.

\section{Results}

\subsection{Characterization of HRC Users}

In 2018, most of the people under HRC treatments were male $(65.8 \% ; 2861 / 4344)$, with a mean age of 63.9 years \pm 19.4 standard deviation (sd). The majority $(73.4 \%)$ of the users were between 46 and 80 years of age, and $40 \%$ were between 66 and 80 years old. When the characterization is performed taking the type of HRC into account, it can be verified that the population requiring oxygen therapy treatments is older (mean age 66 years $\pm 19.9 \mathrm{sd}$ ) compared to patients requiring ventilation therapy (mean age 63.1 years $\pm 19.1 \mathrm{sd}$ ).

\subsection{Evolution of HRC Users (2014-2018)}

Between 2014 and 2018 (Table 1), the average annual growth of people with respiratory disease under HRC treatment was 3.5\% (5.1\% in 2015, 3.4\% in 2016, $-0.8 \%$ in 2017, and $6.1 \%$ in 2018). In these five years, the total number of people with respiratory disease treated through HRC increased by $14 \%$, from 3796 (2014) to 4344 (2018). In 2018, 66\% of the treatments provided were ventilation therapy, followed by $28 \%$ oxygen therapy (mostly long-term oxygen therapy, $17 \%$ ), aerosol therapy (3.9\%), and other treatments $(2.3 \%)$. 
Table 1. Number of home respiratory care (HRC) users by year and therapy.

\begin{tabular}{|c|c|c|c|c|c|c|c|c|c|c|c|}
\hline Year & \multicolumn{2}{|c|}{2014} & \multicolumn{2}{|c|}{2015} & \multicolumn{2}{|c|}{2016} & \multicolumn{2}{|c|}{2017} & \multicolumn{2}{|c|}{2018} & $\%$ Variation $2018 / 2014$ \\
\hline $\begin{array}{l}\text { Number of patients } \\
\text { underHRC treatment }\end{array}$ & \multicolumn{2}{|c|}{3796} & \multicolumn{2}{|c|}{3988} & \multicolumn{2}{|c|}{4125} & \multicolumn{2}{|c|}{4093} & \multicolumn{2}{|c|}{4344} & $14.4 \%$ \\
\hline \multicolumn{12}{|c|}{ Therapies } \\
\hline Nr. of therapies & \multicolumn{2}{|c|}{4297} & \multicolumn{2}{|c|}{4514} & \multicolumn{2}{|c|}{4715} & \multicolumn{2}{|c|}{4684} & \multicolumn{2}{|c|}{4952} & $15.2 \%$ \\
\hline \multicolumn{12}{|c|}{ Type and subtype of therapies ${ }^{2}$} \\
\hline Aerosol therapy & 450 & $(10.5 \%)$ & 289 & $(6.4 \%)$ & 245 & $(5.2 \%)$ & 279 & $(6.0 \%)$ & 194 & $(3.9 \%)$ & $-56.9 \%$ \\
\hline Oxygen therapy & 1263 & $(29.4 \%)$ & 1334 & $(29.6 \%)$ & 1445 & $(30.6 \%)$ & 1316 & $(28.1 \%)$ & 1383 & $(27.9 \%)$ & $9.5 \%$ \\
\hline Ventilation adjuvant & 45 & $(1.0 \%)$ & 77 & $(1.7 \%)$ & 80 & $(1.7 \%)$ & 88 & $(1.9 \%)$ & 66 & $(1.3 \%)$ & $46.7 \%$ \\
\hline Ambulation & 56 & $(1.3 \%)$ & 183 & $(4.1 \%)$ & 253 & $(5.4 \%)$ & 260 & $(5.6 \%)$ & 319 & $(6.4 \%)$ & $469.7 \%$ \\
\hline Short-term oxygen therapy & 184 & $(4.3 \%)$ & 112 & $(2.5 \%)$ & 148 & $(3.1 \%)$ & 116 & $(2.5 \%)$ & 110 & $(2.2 \%)$ & $-40.2 \%$ \\
\hline Long-term oxygen therapy & 925 & $(21.5 \%)$ & 929 & $(20.6 \%)$ & 920 & $(19.5 \%)$ & 802 & $(17.1 \%)$ & 844 & $(17.0 \%)$ & $-8.8 \%$ \\
\hline Palliative & 53 & $(1.2 \%)$ & 33 & $(0.7 \%)$ & 44 & $(0.9 \%)$ & 50 & $(1.1 \%)$ & 44 & $(0.9 \%)$ & $-17 \%$ \\
\hline Other treatments & 94 & $(2.2 \%)$ & 114 & $(2.5 \%)$ & 126 & $(2.7 \%)$ & 129 & $(2.8 \%)$ & 115 & $(2.3 \%)$ & $22.3 \%$ \\
\hline \multicolumn{12}{|c|}{ Nr. of patients with 1 or more therapies } \\
\hline 2 types of therapy & 257 & $(6.8 \%)$ & 283 & $(7.1 \%)$ & 284 & $(6.9 \%)$ & 293 & $(7.2 \%)$ & 288 & $(6.6 \%)$ & $12.1 \%$ \\
\hline 3 types of therapy & 28 & $(0.7 \%)$ & 22 & $(0.6 \%)$ & 26 & $(0.6 \%)$ & 28 & $(0.7 \%)$ & 27 & $(0.6 \%)$ & $-3.6 \%$ \\
\hline 4 types of therapy & 3 & $(0.1 \%)$ & 1 & $(0.0 \%)$ & 2 & $(0.0 \%)$ & 1 & $(0.0 \%)$ & 3 & $(0.1 \%)$ & $0.0 \%$ \\
\hline
\end{tabular}

Legend: Nr.: Number. ${ }^{1}$ Since home respiratory care is a chronic and long-term treatment, the same person may be considered in different years, and thus we have not presented the sum of people in different years. ${ }^{2}$ The same person may have different subtypes of treatment. 
On average, each person received 1.14 treatments. The proportion of people with illness using one or more types of treatment remained unchanged in the interval between 2014 and 2018, with the majority presenting one type of treatment $(93 \%)$ or two treatments simultaneously $(7 \%)$. While in recent years there has been a slight growth in oxygen therapy $(9.5 \%)$ and a more significant increase in ventilation therapy $(31 \%)$, there was a significant decrease in aerosol therapy $(-57 \%)$.

It should be noted that in the field of oxygen therapy, the most accentuated growth was seen in oxygen therapy as an adjuvant to ventilation therapy (a consequence of increased ventilation therapy) and in ambulation oxygen therapy, with values in 20185.7 times higher than those in 2014.

\subsection{Evolution of HRC Prescriptions (2014-2018)}

Over the period under review, the number of prescriptions (Table 2 ) increased by $8.7 \%$ between 2014 and 2016 (from 43,417 to 58,893, $p<0.01$ ), decreasing in 2017 to 15,453 prescriptions and in 2018 to $9419(p<0.01)$. If we analyse the variation in the total number of prescriptions between 2018 and 2014, there is a 78\% reduction-a significant reduction that is evidenced notwithstanding the type and subtype of treatment, type of prescription, and clinical context. This situation reflects (i) the fact that at the beginning of the PEM-CRD process every month of therapy was equivalent to a "one paper" prescription, (ii) the beginning of the process of dematerialization of the PEM-CRD, and (iii) the extension of the expiration period of electronically processed prescriptions.

When evaluating the percentage of prescriptions per type of treatment we observed that in 2018 $69 \%$ of the prescriptions were related to ventilation therapy and $24 \%$ were related to oxygen therapy. Regarding the type of prescription, the percentage of initial prescriptions decreased from $65 \%$ in 2014 to $17 \%$ in $2018(p<0.01)$. This resulted in an increase in continuation/renewal prescriptions (from 34\% to $78 \%, p<0.01$ ) between the years under review. This phenomenon is justified by the implementation of PEM-CRD in 2014, when people already receiving active treatment were introduced for the first time to the platform in the form of an initial prescription, thus making a bias of "false initials". The renewal prescriptions followed the same trend for the same reason: in 2014 they represented 34\% of the total prescriptions, in 2015 they represented 51\% of total prescriptions, and in 2018 (the year in which there was already stability of the data on the PEM-CRD platform) they represented $78 \%$ of prescriptions. In 2018, therefore, the initial, renewal, and modification prescription types represented $16 \%, 78 \%$, and $6 \%$ respectively. 
Table 2. Number of prescriptions of HRC by year.

\begin{tabular}{|c|c|c|c|c|c|c|}
\hline Year & 2014 & 2015 & 2016 & 2017 & 2018 & $\%$ Variation $2018 / 2014$ \\
\hline Total of prescriptions & 43,417 & 51,358 & 58,893 & 15,453 & 9419 & $-78.3 \%$ \\
\hline \multicolumn{7}{|l|}{ Treatments: } \\
\hline Aerosol therapy & $4100(9.4 \%)$ & $2245(4.4 \%)$ & $3266(5.5 \%)$ & $1022(6.6 \%)$ & $468(5.3 \%)$ & $-88.6 \%$ \\
\hline Other treatments & $895(2.1 \%)$ & $1418(2.8 \%)$ & $1418(2.4 \%)$ & $373(2.4 \%)$ & $226(2.4 \%)$ & $-74.7 \%$ \\
\hline Oxygen therapy & $10,067(23.2 \%)$ & $12,886(25.1 \%)$ & $14,508(24.6 \%)$ & $3539(22.9 \%)$ & $2274(24.1 \%)$ & $-77.4 \%$ \\
\hline Adjuvant vent. therapy & $393(0.9 \%)$ & $714(1.4 \%)$ & $977(1.7 \%)$ & $252(1.6 \%)$ & $115(1.2 \%)$ & $-70.7 \%$ \\
\hline Ambulation & $332(0.8 \%)$ & $1596(3.1 \%)$ & $2381(4.0 \%)$ & $651(4.2 \%)$ & $503(5.3 \%)$ & $51.5 \%$ \\
\hline Short-term oxygen therapy & $853(2.0 \%)$ & $557(1.1 \%)$ & $781(1.3 \%)$ & $236(1.5 \%)$ & $131(1.4 \%)$ & $-84.6 \%$ \\
\hline Long-term oxygen therapy & $8284(19.1 \%)$ & $9834(19.1 \%)$ & $10,060(17.1 \%)$ & $2269(14.7 \%)$ & $1404(14.9 \%)$ & $-83.1 \%$ \\
\hline Palliative & $205(0.5 \%)$ & $185(0.4 \%)$ & $309(0.5 \%)$ & $131(0.8 \%)$ & $121(1.3 \%)$ & $-41.0 \%$ \\
\hline Ventilation therapy & $28,355(65.3 \%)$ & $34,809(67.8 \%)$ & $39,701(67.4 \%)$ & $10,519(68.1 \%)$ & $6451(68 \%)$ & $-77.2 \%$ \\
\hline \multicolumn{7}{|l|}{ Prescription type: } \\
\hline Initial & $28,172(64.9 \%)$ & $23,912(46.6 \%)$ & $6516(11.1 \%)$ & $2045(13.2 \%)$ & 1585 (16.8\%) & $-94.4 \%$ \\
\hline Renewal & $14,747(34.0 \%)$ & $26,316(51.2 \%)$ & $51,195(86.9 \%)$ & $12,983(84.0 \%)$ & $7302(77.5 \%)$ & $-50.5 \%$ \\
\hline Modification & $498(1.1 \%)$ & $1130(2.2 \%)$ & $1182(2.0 \%)$ & $425(2.8 \%)$ & $532(5.6 \%)$ & $6.8 \%$ \\
\hline \multicolumn{7}{|l|}{ Clinical context: } \\
\hline Hospital care & $26,709(61.5 \%)$ & $25,701(50.0 \%)$ & $32,375(55.0 \%)$ & $8277(53.6 \%)$ & $5426(57.6 \%)$ & $-79.7 \%$ \\
\hline Primary care & $16,708(38.5 \%)$ & $25,657(50.0 \%)$ & $26,518(45.0 \%)$ & $7176(46.4 \%)$ & $3993(42.4 \%)$ & $-76.1 \%$ \\
\hline
\end{tabular}




\subsection{HRC Prescriptions and Users (2014-2018)}

Throughout the study (2014-2018) we identified that the majority of prescriptions ( $>50 \%$ ) were prescribed in a hospital context. Between 2014 and 2018, there was a decrease in the proportion of prescriptions from hospital care in comparison to that of primary health care. While in 2014 about $62 \%$ of prescriptions were passed through hospital care, in 2018 the percentage dropped to $58 \%(p<0.01)$. When comparing the number of prescriptions with the number of people with respiratory disease under HRC treatments per year (Figure 1), it is possible to verify that although the number of people requiring prescriptions to treat this disease has globally remained stable over the past four years (with an increase of $6.1 \%$ from 2017 to 2018, and $14.4 \%$ from 2014 to 2018), the number of prescriptions suffered a significant break from 2016 onwards $(>75 \%, p \leq 0.05)$ and this is justified by the implementation of the dematerialization of PEM-CRD.



Figure 1. Number of prescriptions and HRC users in each year of study (2014-2018).

\section{Discussion}

To the best of the authors' knowledge, this study constitutes the first worldwide analysis on the impact of electronic prescriptions which focuses on all home respiratory care services, including home mechanical ventilation, oxygen therapy, aerosol therapy, and other HRC treatments, allowing a wider perspective on the role of digital tools in healthcare treatments [10] and beyond medicines [21]. Furthermore, this is the first study to characterize HRC with centralized, official, and real data in Portugal, which is crucial in order to better signal, understand, and improve healthcare provision for respiratory patients.

The growth trend in the overall number of patients with chronic respiratory diseases observed in this study is in line with the worldwide evidence that suggests an increase of these pathologies in the last decade [22,23]. The non-significant increase in the number of patients undergoing oxygen therapy found between 2014 and 2018 is consistent with European trends that show a stabilization in the prevalence of COPD [4]. In this context, the combination of different public health policies (in which the greater regulation of tobacco consumption stands out) and mainly the underdiagnosis of this disease $[3,8,24]$ may help explain the trend for lower growth observed in this study. On the other hand, in the same period we verified a significant increase $(p>0.01)$ in patients on ambulation oxygen therapy. Despite liquid oxygen being available in the Lisbon region since the year 2000, only after the beginning of the national public tender "CP 2013/100" in 2014 has portable oxygen therapy been implemented at a national level, allowing broader access to ambulatory oxygen. It is internationally recognized that this therapy allows greater autonomy and the realisation of activities of daily life outside the home-a fact that benefits the quality of life of people with respiratory disabilities [25]. Thus, this increase can be explained by better medical knowledge and easier access to these therapies, helped by the fact that they were first defined in the Portuguese clinical guidelines in 2015 [14]. Moreover, when considering the reduction of patients treated with oxygen therapy for a long duration in this period, there is a 
possible migration of people with long-term oxygen (LTO) requirements moving to portable oxygen therapy for ambulation. Additionally, the reduction in patients on short-term oxygen therapy and aerosol therapy can be attributed to the implementation of clinical best practices, namely the restriction in prescribing these therapies in the absence of all clinical information according to these guidelines.

The data presented in this manuscript also indicate a 30\% increase in users of ventilation therapy in five years (approximately $7.5 \%$ per year). Of all types of home respiratory care treatments analysed in this study, this was the one that most contributed to the growth of this care. Although there are still few epidemiological studies in Portugal related to sleep apnea syndrome, the ageing of the population, the high prevalence of obesity, and especially the investment in the early diagnosis of this pathology may contribute to this increase in the number of patients undergoing ventilation therapy $[5,6]$.

We highlight the significant number of users with more than one type of home respiratory care treatments: the data indicate that approximately $7 \%$ of users require more than one type of treatment simultaneously. This result is in line with the growth of chronic diseases in Portugal in recent decades [5] and the high number of people in situations of multimorbidity [3,22,26,27]. These factors should act as an incentive for the creation of a programme of "integrated management of the chronic respiratory patient", since currently the renewal of prescriptions in different clinical contexts is done according to the prescribed therapy and not according to the patient. This can lead to a situation where a patient receiving three therapies has to renew them on different dates and in different places (in hospital and primary care).

Regarding the analysis carried out on the number of prescriptions between 2014 and 2018, the data seem to reflect the organizational changes in the model of home respiratory care in Portugal. In this context, it is emphasized that at the end of 2013, the prescription of home respiratory care started to be performed electronically due to Order Nr. 9309/2013 of 16 July [19], which incorporated the norms for clinical guidance of the Portuguese General Health Directorate. The high increase observed between 2014 and 2016 could be mistaken for a high increase in new patients, but is instead explained by the growing acceptance of this tool by the medical prescribers, in addition to the inclusion of the data on the system. In fact, not only initial prescriptions (corresponding to new users or new therapies provided) are prescribed, but also renewal prescriptions for chronic patients who have prolonged treatment. In fact, during the period under review, the growth in renewal prescriptions was accompanied by a decrease in initial prescriptions. This evolution was particularly evident as of 2016, which can be explained by the continued treatment of chronic patients who were introduced to the electronic medical prescription system earlier this year. With regard to the clinical context of prescriptions, in order to ensure the introduction of patients undergoing chronic HRC therapy in the system, an exception to the PEM-CRD in relation to Portuguese clinical guidelines (between 2014 and December 2015) was made which allowed the initial prescriptions to be done by primary health care services [6]. This factor seems to have had an impact on the growth in the proportion of users with prescriptions from primary health care which is observed in 2015.

Our study presents several limitations. Firstly, it is drawn from the prescriptions of users residing in the CHULC's geographical area of influence, which represents a portion of users from the Lisbon metropolitan area. Despite the fact that a high proportion of the Lisbon population is covered by these hospitals, the results should be viewed with caution, and more studies with larger samples are needed to fully understand the trends of these pathologies in the overall Portuguese population. Secondly, it was not possible to obtain the data regarding the two main subtypes of ventilation therapy (CPAP and non-invasive ventilation (NIV)). Thirdly, this study does not include the stakeholders' perceptions of the implementation of the PEM-CRD (i.e., medical prescribers, patients, and homecare providers), especially regarding the negative impact on the ability to invoice all services provided, due to the dependency of a prescription renewal process that leads to a continuous lack of prescriptions and consequent billing inefficiency.

On other hand, the present study allows us to confirm that the implementation of the digital prescription tool PEM-CRD, and the consequent dematerialization of the process, increased the 
efficiency of prescriptions for home respiratory care in Portugal. Furthermore, the possibility of obtaining data through the PEM-CRD computer system allows the monitoring of the evolving prevalence of therapies and optimizes processes, creating a substantial window of opportunity to improve the course of the persons undergoing chronic treatment with home respiratory care therapies, who are still very much dependent on the hospital contexts to renew their prescription.

\section{Conclusions}

The analysis of the prevalence and number of prescriptions of people with chronic respiratory diseases receiving home respiratory care in the Lisbon metropolitan area during the 2014-2018 period, using the information obtained by the Medical Electronic Prescription for HRC services (PEM-CRD) database, allows us to conclude that: (i) in 2018, about $70 \%$ of the prescriptions were related to ventilation therapy and $24 \%$ were related to oxygen therapy; (ii) a meaningful decrease in HRC prescriptions in 2017 and $2018(p<0.01)$ after the implementation of PEM-CRD was verified; and (iii) regarding the type of prescription, the initial prescriptions significantly decreased $(p<0.01)$ from $65 \%$ (2014) to $17 \%$ (2018), while an increase in continuation/renewal prescriptions (from $34 \%$ to $78 \%, p<0.01$ ) between the years under review was identified. Moreover, this study represents a significant contribution in characterizing and improving an innovative digital process regarding the implementation and use of digitalization to advance transparency, knowledge, and sustainability in HRC.

Author Contributions: Conceptualization, M.J.V. and A.E.; Data curation, R.A., C.C., and A.I.S.; Investigation, R.A., A.I.S., and P.B.; Methodology, A.E.; Project administration, J.P. and A.E.; Resources, J.C., J.P., and A.E.; Supervision, M.J.V. and A.E.; Writing—original draft, R.A. and C.C.; Writing—review and editing, R.A., C.C., A.I.S., P.B., J.C., P.C., M.J.V., J.P., and A.E. All authors have read and agree to the published version of the manuscript.

Funding: This research received no external funding.

Acknowledgments: The authors acknowledge to the former Board President of SPMS Henrique Martins for facilitating the access to official data of the Medical Electronic Prescription for Home Respiratory Care (PEM-CRD) from the Portuguese Ministry of Health that allowed us to perform the study, the Executive Administration Board of the Centro Hospitalar Lisboa Central, and the National School of Public Health Executive Board for their contributions to the development of this study.

Conflicts of Interest: The authors declare no conflict of interest.

\section{References}

1. Despacho n. ${ }^{\circ}$ 9405/2014, de 21 de Julho. Ministério da Saúde-Gabinete do Secretário de Estado da Saúde. Diário da República n. ${ }^{\circ}$ 138/2014, Série II de 2014-07-21. Available online: https://dre.pt/pesquisa/-/search/ 55028303/details/normal?p_p_auth=JvT5FiDw (accessed on 12 October 2020).

2. Caneiras, C.; Jacome, C.; Mayoralas-Alises, S.; Ramon-Calvo, J.; Fonseca, J.A.; Diaz-Lobato, S.; Escarrabill, J.; Winck, J.C. Patient experience with home respiratory therapies in Portugal: It is time to move forward. Pulmonology 2019, 25, 311-312. [CrossRef] [PubMed]

3. Adeloye, D.; Chua, S.; Lee, C.; Basquill, C.; Papana, A.; Theodoratou, E.; Nair, H.; Gasevic, D.; Sridhar, D.; Campbell, H.; et al. Global and regional estimates of COPD prevalence: Systematic review and meta-analysis. J. Glob. Health 2015, 5, 020415. [CrossRef] [PubMed]

4. Wedzicha, J.A.E.C.-C.; Miravitlles, M.; Hurst, J.R.; Calverley, P.M.; Albert, R.K.; Anzueto, A.; Criner, G.J.; Papi, A.; Rabe, K.F.; Rigau, D.; et al. Management of COPD exacerbations: A European Respiratory Society/American Thoracic Society guideline. Eur. Respir. J. 2017, 49, 1600791. [CrossRef] [PubMed]

5. Antunes, A.F.; Bárbara, C.; Gomes, E.M. Programa Nacional para as doenças respiratórias (2012-2016). Direção Geral da Saúde. 2013. Available online: https://www.dgs.pt/documentos-e-publicacoes/programanacional-para-as-doencas-respiratorias-2012-2016-pdf.aspx (accessed on 12 October 2020).

6. Bárbara, C.; Jara, E.S. Programa Nacional Para as Doenças Respiratórias-Regras de Prescrição de Cuidados Respiratórios Domiciliários. Direção Geral da Saúde. 2015. Available online: https://comum.rcaap.pt/bitstream/ 10400.26/15280/1/i022038.pdf (accessed on 12 October 2020).

7. Punjabi, N.M. The epidemiology of adult obstructive sleep apnea. Proc. Am. Thorac. Soc. 2008, 5, 136-143. [CrossRef] [PubMed] 
8. Dretzke, J.; Moore, D.; Dave, C.; Mukherjee, R.; Price, M.J.; Bayliss, S.; Wu, X.; Jordan, R.E.; Turner, A.M. The effect of domiciliary noninvasive ventilation on clinical outcomes in stable and recently hospitalized patients with COPD: A systematic review and meta-analysis. Int. J. Chronic Obstruct. Pulm. Dis. 2016, 11, 2269-2286. [CrossRef] [PubMed]

9. Miravitlles, M.; Vogelmeier, C.; Roche, N.; Halpin, D.; Cardoso, J.; Chuchalin, A.G.; Kankaanranta, H.; Sandstrom, T.; Sliwinski, P.; Zatloukal, J.; et al. A review of national guidelines for management of COPD in Europe. Eur. Respir. J. 2016, 47, 625-637. [CrossRef] [PubMed]

10. Escarrabill, J.; Tebe, C.; Espallargues, M.; Torrente, E.; Tresserras, R.; Argimon, J.; en nombre del equipo del Plan Director de las Enfermedades del Aparato Respiratorio y del Observatorio de Terapias Respiratorias. Variability in home mechanical ventilation prescription. Arch. Bronconeumol. 2015, 51, 490-495. [CrossRef] [PubMed]

11. Dybwik, K.; Tollali, T.; Nielsen, E.W.; Brinchmann, B.S. Why does the provision of home mechanical ventilation vary so widely? Chronic Respir. Dis. 2010, 7, 67-73. [CrossRef] [PubMed]

12. Despacho n. ${ }^{\circ}$ 9483/2014, de 22 de Julho. Ministério da Saúde-Gabinete do Secretário de Estado da Saúde. Diário da República n. ${ }^{\circ}$ 139/2014, Série II de 2014-07-22. Available online: https://dre.pt/web/guest/pesquisa/ -/search/55025906/details/normal?q=Despacho+n.\%C2\%BA\%209483\%2F2014 (accessed on 12 October 2020).

13. Norma da Direção Geral da Saúde Nº 021/2011, Atualizada a 11/09/2015. Cuidados Respiratórios Domiciliários: Prescrição de Aerossolterapia por Sistemas de Nebulização. Direção-Geral de Saúde. 2015. Available online: https://nocs.pt/aerossolterapia-por-sistemas-de-nebulizacao-domicilio/ (accessed on 12 October 2020).

14. Norma da Direção Geral da Saúde Nº 018/2011, Atualizada a 11/09/2015. Cuidados Respiratórios Domiciliários: Prescrição de Oxigenoterapia. Direção-Geral de Saúde. 2015. Available online: https://nocs.pt/oxigenoterapiadomiciliaria/ (accessed on 12 October 2020).

15. Norma da Direção Geral da Saúde No 022/2011, Atualizada a 11/09/2015. Cuidados Respiratórios Domiciliários: Prescrição de Ventiloterapia e Outros Equipamentos. Direção-Geral de Saúde. Available online: https://nocs.pt/ ventiloterapia-domiciliaria/ (accessed on 12 October 2020).

16. Meen, T.H.; Matsumoto, Y.; Lee, K.H. Special Issue on Clinical Medicine for Healthcare and Sustainability. J. Clin. Med. 2020, 9, 2206. [CrossRef] [PubMed]

17. Caneiras, C.; Jacome, C.; Mayoralas-Alises, S.; Ramon Calvo, J.; Almeida Fonseca, J.; Escarrabill, J.; Winck, J.C. Patient Experience in Home Respiratory Therapies: Where We Are and Where to Go. J. Clin. Med. 2019, 8, 555. [CrossRef] [PubMed]

18. Sousa-Uva, A.; Jara, E.; Castelão, I.; De Almeida, A.B.; Pires Deveza, R.M.M.; Santos, R.; Mariz, S.; Almeida, J.; Moita, J.; Santos, A.C.; et al. Relatório de Situação Cuidados Respiratórios Domiciliários em Portugal. Comissão Nacional Para os Cuidados Respiratórios Domiciliários. 2010. Available online: http://nocs.pt/ wp-content/uploads/2016/06/CNCRD_RELATORIO_BOAS_PRATICAS_12_03_2011vfinal.pdf (accessed on 12 October 2020).

19. Despacho n. ${ }^{\circ}$ 9309/2013, de 16 de Julho. Ministério da Saúde-Gabinete do Secretário de Estado da Saúde. Diário da República n. ${ }^{\circ}$ 135/2013, Série II de 2013-07-16. Available online: https://dre.pt/web/guest/pesquisa/ -/search/2783810/details/normal?q=Despacho+n\%C2\%BA\%209309\%2F2013+de+16+de+julho (accessed on 12 October 2020).

20. Procedimento de Contratação Tendente à Celebração de Acordo Quadro Para a Area da Saúde com Vista à Prestação de Serviços de Cuidados Técnicos Respiratórios Domiciliários. CP 2017/100. Serviços Partillhados do Ministério da Saúde (SPMS). Available online: https://www.catalogo.min-saude.pt/CTAP/downloads/ concursos/CE_2017_100_VF.PDF (accessed on 12 October 2020).

21. Aldughayfiq, B.; Sampalli, S. Digital Health in Physicians' and Pharmacists' Office: A Comparative Study of e-Prescription Systems' Architecture and Digital Security in Eight Countries. OMICS 2020. [CrossRef] [PubMed]

22. Bhatta, L.; Leivseth, L.; Mai, X.M.; Henriksen, A.H.; Carslake, D.; Chen, Y.; Langhammer, A.; Brumpton, B.M. GOLD Classifications, COPD Hospitalization, and All-Cause Mortality in Chronic Obstructive Pulmonary Disease: The HUNT Study. Int. J. Chronic Obstruct. Pulm. Dis. 2020, 15, 225-233. [CrossRef] [PubMed]

23. Neumeier, A.; Keith, R. Clinical Guideline Highlights for the Hospitalist: The GOLD and NICE Guidelines for the Management of COPD. J. Hosp. Med. 2020, 15, 240-241. [CrossRef] [PubMed]

24. Murphy, P.B.; Rehal, S.; Arbane, G.; Bourke, S.; Calverley, P.M.A.; Crook, A.M.; Dowson, L.; Duffy, N.; Gibson, G.J.; Hughes, P.D.; et al. Effect of Home Noninvasive Ventilation With Oxygen Therapy vs Oxygen Therapy Alone on Hospital Readmission or Death After an Acute COPD Exacerbation: A Randomized Clinical Trial. JAMA 2017, 317, 2177-2186. [CrossRef] [PubMed] 
25. Mayoralas Alises, S.; Caneiras, C.; Diaz-Lobato, S. A telephone-based survey of current trends, habits and beliefs in patients receiving portable oxygen therapy in Madrid, Spain. ERJ Open Res. 2019, 5. [CrossRef] [PubMed]

26. Lloyd-Owen, S.J.; Donaldson, G.C.; Ambrosino, N.; Escarabill, J.; Farre, R.; Fauroux, B.; Robert, D.; Schoenhofer, B.; Simonds, A.K.; Wedzicha, J.A. Patterns of home mechanical ventilation use in Europe: Results from the Eurovent survey. Eur. Respir. J. 2005, 25, 1025-1031. [CrossRef] [PubMed]

27. Tan, G.P.; McArdle, N.; Dhaliwal, S.S.; Douglas, J.; Rea, C.S.; Singh, B. Patterns of use, survival and prognostic factors in patients receiving home mechanical ventilation in Western Australia: A single centre historical cohort study. Chronic Respir. Dis. 2018, 15, 356-364. [CrossRef] [PubMed]

Publisher's Note: MDPI stays neutral with regard to jurisdictional claims in published maps and institutional affiliations.

(C) 2020 by the authors. Licensee MDPI, Basel, Switzerland. This article is an open access article distributed under the terms and conditions of the Creative Commons Attribution (CC BY) license (http://creativecommons.org/licenses/by/4.0/). 